\title{
The Apprehensive and Suppressed Soul of the Fallen Woman in Thomas Hardy's Tess of the D'Urbervilles
}

\author{
Noorbakhsh Hooti \\ English Department, Faculty of Arts, Razi University, Kermanshah, Iran \\ Email: nhooti@yahoo.com
}

\begin{abstract}
In Tess of the D'Urbervilles, Hardy brings to picture a helpless innocent country girl who is the victim of Victorian patriarchal society and the injustice of social law. The study makes an attempt to bring to light the injustice of social law, the hypocrisy of social prejudice and the inequality of male-dominance in the Victorian Patriarchal society and shows Hardy's heartfelt commiseration towards Tess, the protagonist, who is the symbolic of rural women who were ruthlessly crushed in male-dominated world. This study further aims at scrutinizing the biased social norms, the unjust laws the rotten ethics and the malicious morality standards, which contribute to Tess's innocent crush.
\end{abstract}

Index Terms - Tess, D'Urbervilles, apprehensive, suppressed, soul

\section{INTRODUCTION}

The study begins with a brief introduction of Hardy's interest towards the downtrodden rights of the women of the Victorian Age, which is followed by a look at different critics commenting on Hardy's women, then the study arrives at its focal point by delving into Hardy's Tess of the D'Urbervilles to display the predicament of woman.

By the end of the nineteenth century, a group of famous novelists, mainly men, began to look sympathetically at the problems of the late nineteenth century women. George Meredith, George Gissing and Thomas Hardy and some others were in favor of the feminists. These writers often discussed the question of free union and their female characters either support themselves or live away from home. To the feminists, Thomas Hardy is one of the few Victorian male novelists who wrote in what may be called 'a female tradition.

Hardy's remarkable heroines evoked comparison with those of Charlotte Bronte, George Eliot and Jane Austen. His heroines spoke directly to women readers. For example, after the publication of Tess of the D'Urbervilles, Hardy received letters from women who had not dared to tell their husbands about their pre-marital experiences. A few begged to meet him privately to confide with him.

Hardy felt that such letters came from sincere women who were really in distress. He also received letters from mothers who were placing Tess of the D'Urbervilles into their daughter's hands to safeguard their future. There is no doubt that Hardy's treatment of the 'Woman Question' in his major novels has done the whole male and female sex a great service. In 1896, Hardy's support to the suffrage campaign was based on his belief that the women's vote will be able to break up the pernicious conventions in respect of manners, customs and the illegitimacy and the parenthood of the offspring. The feminist Black (1892) claims Hardy "as one of that brave and clear-sighted minority who has drawn a distinction between moral worth and simple chastity in women."(p. 50) Howe (1968) while assessing Hardy's work says that the novelist has a "gift for creeping intuitively into the emotional life of women and his openness to the feminine principles." (p. 109)

Recent feminist critics remarked that women characters provide what is missing in the acquisition of masculinity. Miles (1979) says: "A woman in Hardy's hands could be made to bear a weight of suffering whose inflictions transcend the personal and move through human to sublime; he never found the same true of a male character." (pp. 38-39)

The notion of sublimity of suffering is based on the longstanding convention of the moral superiority of women. Hardy tries, through his fictional women to awaken the consciousness of society towards the sufferings and misery of women.

A thorough analysis of Hardy's novel shows that his women characters are misused as well as abused by men.

Hardy felt that it was very important to champion the cause of women because in his view, they were the weaker sex.' It was women who bore children and who were sacrificed to the double standards of morality. They were the ones who most likely got wrecked to pieces if anything went wrong morally. Tess of the D'Urbervilles belongs to the list of the unconventional novels that appeared in the 1890s and it ends with women breaking down under the weight of repressive conditions. Tess of the D'Urebervilles was greatly admired by most readers who were ready to sympathize with the theme of fallen woman, a new tendency which was not familiar to the Victorian readers. It seems that this novel has surpassed the matter of time and it always remains fresh. As Bloom (2010) claims: 
Of all the novels of Hardy, Tess of the d'Urbervilles now appeals to the widest audience. The book's popularity with the common reader has displaced the earlier ascendancy of The Return of the Native. It can even be asserted that Hardy's novel has proved to be prophetic of a sensibility by no means fully emergent in 1891. More than a century later, the book sometimes seems to have moments of vision that are contemporary with us.(p. 12)

\section{ARGUMENT}

The study delves into the silent world of the helpless women by having a journey in Hardy's Tess of the D'Urbervilles. A journey, which brings inevitable tears to any sympathetic eyes that have ever witnessed the unjust treatment of man towards his/her own fellow beings

Tess of the D'Urhervilles (1891) is the pitiable story of Tess Durbeyfield, a peasant working girl, who was seduced by Alec D'Urbervilles and the traumatic experiences she went through which culminated in retributive justice from an uncaring society. In Tess of the D'Urhemilles Hardy attacked the basic moral assumptions of the Victorian Age which condemned the innocent and defenseless victim of a seducer while the actual culprit of the crime was untouched by the law.

Hardy subtitled the novel as "A Pure Woman" out of his own conviction of the essential purity of his heroine. In his preface to the novel, Hardy remarks:

This novel being one wherein the great campaign of the heroine begins after an event in her experience which has usually been treated as fatal to her part of protagonist, or at least as the virtual ending of her enterprises and hopes, it was quite contrary to avowed conventions that the public should welcome the book, and agree with me in holding that there was something more to be said in fiction than had been said about the shaded side of a well-known catastrophe. (1994, p. 21, henceforth Hardy)

Hardy is frank about embodying a recognizable contemporary problem in his novel. His authorial comments reveal a consistency and strength of purpose, which leave no doubt that he is arguing in favor of the fallen woman. Hardy's argument is that though Tess had fallen, she should not be judged by her fall alone but by her own intentions, nature and the circumstances that compelled her to be in this position. Tess was too young when her sexual molestation took place and there was no particular intention or even romantic attachment to Alec. She had to submit herself to the will of her employer, Alec, due to her helpless situation and her ignorance about the consequences of such a relationship.

While expounding violence against women, Nye (1988) observes: "Brownmiller, in her influential Against Our Will placed rape at the threshold of human history as an exercise of male power over women." (p.97)

The controversy about Tess of the D'Urbervilles is about moral values. According to Hardy, Tess's purity lies in her innocence and ignorance for not having received any instructions or self-acquired knowledge on the subject from any source. Nevertheless, Hardy and his heroine attracted tremendous commendations as well as furious uproar. Erring wives wrote to him asking advice and seeking sympathy. Hardy made Tess a living entity. Hardy's challenge of the norms of Victorian Age to defend the rights of women and his sympathy for them are strong proofs of his being a feminist novelist. In the preface to the first edition, Hardy wrote:

In respect of the book's opinion and sentiments, I would ask any too genteel reader, who cannot endure to have said what everybody nowadays thinks and feels, to remember a well-worn sentence of St. Jerome's: If an offence come out of the truth, better is it that the offence come than that the truth be concealed. (Hardy, P. 19)

Here, Hardy defends his opinions forcefully. He attacks his critics logically and even invites public judgment that he deliberately treats the theme of the fallen woman by giving it a new dimension.

Tess is presented to us as an independent and a spirited woman. Her relation with Alec was far from being romantic as it proved to be dangerous with unpredictable consequences later. Like Grace Melbury in The Woodlander, a victim of her father's foolishness and vanity, Tess also was a victim of her mother, Joan Durbeyfield, whose opportunism and folly put Tess in danger in the hands of Alec D'Urberville. She rebuked Tess for failing to obtain a marriage ring from Alec. But Tess, instead, held her mother responsible for what had happened to her:

Why didn't you tell me there was danger in menfolk'? Why didn't you warn me? Ladies know what to fend hands against because they read novels that tell them of these tricks: but I never had the chance of learning in that way, and you didn't help me! (Hardy, p. 111)

Tess blamed her mother for being negligent in educating her about guarding herself. Her mother was interested only in rank and fame at the expense of her daughter's happiness. Hardy suggests that the mother should be the ultimate mentor for her daughter in such a cruel world. Therefore, Tess's mother was partly responsible for her miseries which started in Alec's beastly behavior. In the end, the village gossip and the system of feudal life-tenancy forced Tess into accepting Alec's protection.

Tess's tragedy is also brought out by Alec D'Urberville and Angel Clare. As Rode (2006) comments:

Alec and Angel construct Tess's sexual identity and locate her on their own sexual maps. The tragedy of the novel resides in the irreconcilability of these road practices due to the ignorance in understanding the other, a failure that ultimately overwhelms Tess. (p. 67)

In regard to Alec D'Urberville's role in the novel; it does not invite any sympathy at all. His relationship with Tess during her employment under him was strictly on master-servant basis. Tess's seduction, the birth and death of her illegitimate baby "Sorrow" brought her untold pain and sufferings. The village parson's refusal to baptize the infant 
before its burial made Tess do it herself. Even the burial site allotted to the newborn was in a remote corner of the graveyard usually set aside for bad characters like murderers and law-breakers. The baptism and the burial scene are highly contemptible for a progressive society and Christian tenets as per the unforgiving nature exhibited in both cases. Subbamma (1985) explains:

Religion has condemned women to slavery from birth onwards. Society has restricted the development of her personality. Man has suppressed her talents. It is a pity that we have not realized that it is not woman alone but entire humanity that will suffer on account of oppression of women. (p. 11)

When Angel Clare deserted Tess after marriage, Alec made another attempt to make Tess accept him. He informed her that Angel Clare would never come back to her and once again he reminded her of her little brothers and sisters who needed financial support. Being unselfish and ready to sacrifice for her family, Tess accepted Alec. At this time, Clare came to look for Tess but failed to meet her. On knowing that she had lost Clare for the second time, Tess became desperate. In addition to this, Alec's taunting about Clare whom she still loved, provoked Tess to take the extreme step of killing him. Such action was due to frustration and the pain inflicted on her throughout the course of her life. She was forced to take the law into her own hands because there was no existing law to protect her rights. However, this invited capital punishment from the authorities regardless of the circumstances which forced Tess to commit the crime. Subbamma (1985) says: "The woman has been relegated to the second place, oppressed by society and religion and dominated by man." (ibid)

Angel Clare with whom Tess was involved in a genuine romantic relationship was also equally responsible for Tess's tragic end. After professing unfailing love for Tess, Angel entered into a marriage with Tess, despite her unwillingness and cautious approach. Angel Clare's voluntary confession of a forty-eight hour dissipation with a strange woman was forgiven by Tess. But a similar confession from Tess about her forced sexual violation by Alec and its consequences was unacceptable to Angel Clare. He not only failed to forgive Tess and forget her past but also at that very moment, rejected her as his lawful wife. MacGregor (1987) points out:

A wife might without any loss of caste... condone an act of adultery on the part of the husband, but a husband could not condone a similar act on the part of a wife, and for this among other reasons. . . that the adultery of the wife might be the means of palming suspicious offspring on the husband while the adultery of husband could have no such effect with regard to the wife." (p. 20)

In spite of her earnest pleading that she was a child then, uninstructed and unaware of man-woman relationship, Angel was not at all ready to accept her: "You were more sinned against than sinning, that I admit I forgive you, but forgiveness is not all." (Hardy, p. 268) Tess quoted some cases worse than hers where the men did not mind at all. To this, Clare replied: "Decrepit families imply decrepit wills, decrepit conduct. Heaven, why did you give me a handle for despising you more by informing me of your descent!" (p. 269)

Angel Clare was referring to Tess as a descendant of the D'Urberville family. He was unconcerned and indifferent to Tess about the consummation of their marriage. He urged Tess to say that her confession was not true, but Tess stood firm by her words. We can see here that Hardy's aggressive attack is mounted against the man and the social attitudes he represents. Schneir (1996) says, according to Seneca's Fall's Declaration:

that the same amount of virtue, delicacy and refinement of behaviour that is required of woman in the social state, should also be required of man, and the same transgression should be visited with equal severity on both man and woman. (p. 81)

Angel Clare is a self-consciously modern thinker who shows considerable indifference to social forms and observances. But he fails conclusively at the first test of his emancipation and proves to be deeply entrenched in convention in his attitude to women. His inconsistency demonstrates the unconscious hypocrisy of the moral codes. His change from a liberal agnostic to a puritanical moralist manifests how deep sexual prejudices are rooted even among progressive people. Angel Clare resembles Henry Knight in Pair of Blue Eyes in his conventional attitude towards women. Like Angel Clare, Knight demands perfection in the woman he marries and when he discovers that Elfride has loved another man, he feels that she is an imposter. Both of them fall in love with a moral quality rather than a woman. When Elfride realizes this, she retorts by saying:

Am I such a - mere characterless toy - as to have no attraction in me, apart from-freshness? Haven't I brains? You said-I was clever and ingenious in my thoughts, and-isn't that anything?. . You have praised my voice, and my manner, and my accomplishments. Yet all these things together are so much rubbish because I—accidentally saw a man before you! (Hardy, 1975, p. 365)

When he learns about Elfride's overnight escape with Stephen Smith, he jumps to the conclusion that Elfride is a fallen woman and starts reacting as a representative of social morality. He is wrong about Elfride as she has spent the night quite chastely. His attitude to women has been traditional like Angel Clare:

Elfride loved him, he knew, and he couldn't leave off loving her, but marry her he would not. If she could but be again his own Elfride - the woman she had seemed to be-but that woman was dead and buried, and he knew her no more! (p. 389)

However, both Tess and Angel Clare were also guilty of idealizing each other and that was the reason for the failure of their marriage as much as the double moral standards and cruel social laws. Angel Clare could not bear the knowledge of Tess's liaison with Alec because he wanted to believe that Tess was a symbol of purity. This can be seen 
in his immediate reaction after Tess made her confession: "You were one person; now you are another . . . the woman I have been loving is not you." (Hardy, pp. 264-65) Tess realized that Angel's response was absurd:

I thought, Angel, that you loved me-me, my very self?. If it is I you do love, O how can it be that you look and speak so'? It frightens me! Having begun to love you, I love you for ever-in all changes, in all disgraces, because you are yourself. I ask no more. Then how can you, O my husband, stop loving me? (ibid)

We can see that Angel Clare, an advanced and well meaning young man, was still a slave to custom and conventionality. The idealistic sexual prejudice overpowered his intelligence and tenderness. In this context, Hardy contends:

The basic flaw in Angel is a morbid idealism - an idealism, derived from certain human institutions, certain social attitudes prevalent in his time and class, which has gone bad and become negative. (p. 17)

However, Tess too idealized Angel Clare with whom she was in love. It was because she almost worshipped Clare, looking up to him for advice and guidance in everything, that she was unable to see his moral judgement of her as simply wrong. She accepted his decision to leave her without any protest or hesitation. Such passivity is taken as a basic flaw in the character of Tess:

I shan't do anything, unless you order me to: and if you go away from me I shall not follow 'cc and if you never speak to me anymore I shall not ask why, unless you tell me I may. (p. 266)

De Beauvoir (1988) explains:

The woman in love who before her lover is in the position of the child before its parents is also liable to that sense of guilt she felt with them; she chooses not to revolt against him as long as she loves him, but she revolts against herself. If he loves her less than she wants him to; if she fails to engross him, to make him happy to satisfy him, all her narcissism is transformed into self-disgust, into humiliation, into hatred of herself, which drive her to self-punishment. (pp. 661-62)

Hardy asserts the dangerous state of such relationship based not on real understanding but on false, self-induced vision of the other person. Tess surrendered totally and resigned to her fate as she saw Clare infallible, almost godlike. Subbamma (1985) states:

Tradition has equated service and devotion to husband as equivalent to a higher and nobler life in world of gods. That is why women worship their husbands as 'living gods,' they sing their praise and beg for favours. In return, they receive nothing but humiliation. (p. 12)

Another factor of Tess's misfortune is that she too has absorbed the false moral code in the course of events. She is prepared to accept Clare's judgment of her even though her instincts tell her that he is a hypocrite. Hardy points out that in blaming herself for her seduction by Alec, Tess substituted a false idea of sexuality for a natural one. Hardy says that her own poor opinion of herself and her conduct is:

Based on shreds of convention, peopled by phantoms and voices antipathetic to her, was a sorry and mistaken creation of Tess's fancy - a cloud of moral hobgoblins by which she was terrified without reason. It was they that were out of harmony with the actual world, not she. (p. 114)

Hardy blames social institution and religious establishments for Tess's sufferings as most of her miseries have been generated by her own conventional aspect and not by her innate sensitivity. Schneir (1996) refers to Elizabeth Cady Stanton saying, "Ow laws and constitutions, our creeds and codes, and the custom of social life are all of masculine origin'?" ( p. 28)

However, lovers in Hardy's novels find happiness only when both partners have tenderness for each other, for happiness begets happiness. Angel Clare and Tess find true happiness only when Angel learns to care for Tess and her happiness more than for his convictions and principles. In this regard, Hugman (1970) states: "The two halves of the 'perfect whole' come together for a few brief moments which seem to be as much as human frailty can bear. But they are unique and glorious moments." (pp. 60-61)

In the final analysis, Tess is portrayed as the most admirable character in the novel while the other two men in her life are depicted as the victims of false human ideals. Alec believed that he could play 'the master' to the peasant girl and Angel too believed that there was some kind of mystic purity in the lower classes. Both these characters have destructive notions as they replace individual human values with false concepts of social behaviour. As Mallett (2002) says:

More specifically, both Alec d'Urberville and Angel Clare find their self-conception of masculinity endangered by their desire for Tess. This danger increases when each becomes aware of the other's existence as a rival, because it forces them to confront the precarious status of the masculine identity they have constructed. Their destruction of Tess is a direct result of their attempt to stabilise that identity, and in so doing defeat the rival who embodies an alternative vision of self which they cannot accept. (p. 88)

Again it is observed that Angel is obsessed with the idea of feminine purity and a sceptic lacking in compassion. His ambivalent feelings are clouded by his desire to break free of his religious and social background. But such desires are seen not strong enough to withstand the confession-scene. When Tess confesses her past to him, Angel becomes too blinded by his idealistic notions. Yet, he has a genuine love for Tess which lies beneath his conscious self. The scene of Angel's sleep-walking carrying Tess across the river prepares the readers for his final realization of his true sentiments for her. However, Angel Clare is inconsistent in character. He complains about the social ordinances of marriage as 
constraining, when his own view of purity in his wife binds him more to the social law. He is self-alienated and one of the most complex and contradictory of Hardy's male characters.

Tess of the D'Urhervilles emphasizes also the effect of the abstract concepts about conduct. Through Angel's characterization, Hardy illustrates that life-denying ideas are extremely destructive in effect. In this novel, Hardy lifts the tale of a wronged peasant girl into the realm of tragedy. It is not only the tale of Tess Durbeyfield but also the story of sufferings and subordination of any woman. It is about a pure soul struggling against the evils of double standards and the pretentious moral and social forces. It also stands as a sustained attack on false morality with its inflexible demand for purity in women only. It reduced Tess to terrible poverty and drove her back to Alec D'Urbervilles.

In regard to the subordination and resignation of women, De Beauvoir (1988) says:

This resignation inspires the patience often admired in women. They can stand physical pain much better than men: they are capable of stoical courage when circumstances demand it; lacking the male's aggressive audacity; many women distinguish themselves by their calm tenacity in passive resistance. (p. 613)

Tess's meekness and endurance in her love for Angel Clare evoke bitter emotions which pierce the stoniest moral heart. In her last letter to Angel, she pours out her frustration and anger:

O why have you treated me so monstrously, Angel! I do not deserve it. I have thought it all over carefully, and 1 can never; never forgive you! You know that I did not intend to wrong you-why have you so wronged me? You are cruel, cruel indeed? I will try to forget you. It is all injustice I have received at your hands!

It is quite true!" said Angel, throwing down the letter. (p. 414)

But such response is late; it is even seen as an important change in Angel's attitude. In the end, Tess herself realizes that she was mistaken in accepting Clare's estimate of her.

\section{CONCLUSION}

Tess is the symbol of a country girl who is the victim of social prejudice and male dominance. She is easily swallowed by the brutal beasts of the sexually dominated cannibals of the patriarchal Victorian society. In this society woman is culturally constructed, rather than biologically defined. As Harvey (2003) comments:

The Victorian middle class image of women was culturally controlled.

They were denied political and economic power, and were expected to conform to the idea of separate spheres for men and women. (p. 34)

Tess is caught up in the tragic trap of the brutal social injustice of imposed marriage and sexuality. Finally the study comes to its conclusion by claiming that Tess and Tess like women will always remain the sexual entertainers of the wanton men who see the women nothing more than mere objects for their sexual satisfaction until and unless they start believing in their own autonomy, identity, and this can be only feasible through education. Through education one can gain mental might. It is through the mental might that a woman can stand against the physical might of a man and can stand beside a man claiming the equal social and political status free from any suppression and apprehension. As Bishop (2009, p. 171) quotes Goethe, "'the whole art of life consists in giving up our existence in order to exist.'”

\section{REFERENCES}

[1] Bishop, P. (2009). Analytical Psychology and German Classical Aesthetics: Goethe, Schiller, and Jung. Volume 2: The Constellation of the Self. London: Routlege.

[2] Black, C. (1892). “Tess of the D’Urebervilles,'” Illustrated London News, 9, 50.

[3] Bloom, H. (2010). Bloom's Modern Critical Views: Thomas Hardy-New Edition. New York: Infobase Publishing.

[4] De Beauvoir, S. (1988). The Second Sex. Britain: Picador.

[5] Hardy, T. (1994. rprnt). Tess of the D’Urbervilles. New Delhi: Rupa.

[6] Hardy, T. (1975. rprnt) A Pair of Blue Eyes. London: Macmillan.

[7] Harvey, G. (2003). The Complete Critical Guide to Thomas Hardy. London: Routledge.

[8] Howe, I. (1968). Thomas Hardy. London: Weidenfield and Nicolson.

[9] Hugman, B. (1970). Hardy: Tess of the D'Urbevilles. London: Edward Arnold.

[10] Mallette, P. (2002). Thomas Hardy: Texts and Contexts. New York: Palgrave Macmillan.

[11] McGregor, O.R. (1987). Divorce in England. London: Heinemann.

[12] Miles, R. (1979). “The Women of Wessex". Ann. Smith ed. London: Vision.

[13] Nye, A. (1988). Feminist Theory and the Philosophies of Man. New York: Routledge.

[14] Rode, S. (2006). Reading and Mapping Hardy's Roads. New York: Routledge.

[15] Schineir, M. (1996). The Vintage Book of Historical Feminism. U.K: Vintage.

[16] Subbamma, M. (1985). Women: Tradition and Culture. New Delhi: Sterling.

Noorbakhsh Hooti is currently an Assistant Professor of English Language and Literature at Kermanshah Razi University, Iran. His main interests of research are drama, Short Story and Novel. He has a deep interest in postmodern and as well as postcolonial literature. He has been engaged in teaching English language and Literature for more than fifteen years. He holds Ph. D. in English Language and Literature, M. A. in English Language and Literature, and B.A in English Language and Literature. He has published a number of books, Research Projects, and articles in his areas of interest in academic journals. 